\title{
Pengaruh Pergerakan Putar Balik Arah terhadap Kinerja Ruas Jalan Letjen Hertasning Kota Makassar
}

\author{
Rani Bastari Alkam ${ }^{1}$, Muh. Ilham Marhabang ${ }^{2}$, Muh. Ikhwan ${ }^{3}$ \\ ${ }^{1,2,3}$ Program Studi Teknik Sipil Universtas Muslim Indonesia, \\ Jl. Urip Sumoharjo KM 05, Kota Makassar Sulawesi Selatan 90234 \\ E-mail: ${ }^{1}$ rani.bastari@umi.ac.id, ${ }^{2}$ ilhambollo@gmail.com, ${ }^{3}$ muhikhwan09@gmail.com
}

\begin{abstract}
Kata Kunci
Bukaan median; karakteristik lalu lintas; putar balik arah; ruas jalan; tingkat pelayanan
\end{abstract}

\begin{abstract}
Abstrak
Aktivitas putar balik arah pada beberapa bukaan median yang tersedia di sepanjang ruas Jalan Letjen Hertasning disinyalir sebagai pemicu kemacetan lalu lintas sebab pergerakan ini dapat menghambat pergerakan kendaraan pada kedua arah lalu lintas saat kendaraan memerlukan ruang manuver tambahan untuk menyelesaikan gerakan putar balik arah secara penuh. Penelitian ini bertujuan untuk menganalisis pengaruh pergerakan putar balik arah terhadap kinerja ruas jalan pada Jalan Letjen Hertasning Kota Makassar. Survei lalu lintas dilakukan pada lima pos pengamatan yang dipilih pada lima bukaan median pertama Jalan Letjen Hertasning yang berbatasan langsung dengan Jl. AP Pettarani selama tiga hari untuk segmen jam puncak pagi, siang, dan sore hari. Kinerja ruas jalan dianalisis mengikuti prosedur pada Manual Kapasitas Jalan Indonesia. Hasil penelitian menunjukkan bahwa antrian kendaraan saat bermanuver untuk memutar arah khususnya pada jam puncak setara dengan panjang 9 kendaraan atau sepanjang $36 \mathrm{~m}$. Antrian ini menyebabkan kapasitas ruas jalan berkurang sebesar 2,5-10\% dari kapasitas sesungguhnya yang menyebabkan terjadinya penurunan kecepatan, peningkatan derajat kejenuhan, dan penurunan tingkat pelayanan ruas jalan Letjen Hertasning.
\end{abstract}

\section{Keywords}

Level of service; median opening; road segment; traffic characteristic; $U$ turn;

\begin{abstract}
The U-turn movement activities at several median openings available along the Letjen Hertasning road arguably is one of the triggering factors for the occurrence of traffic congestion on that road section because this movement creates hindrances to traffic flow in the same lane and the contra flow when the vehicle requires additional space to complete the movement. The purpose of this study is to reveal the consequence caused by the U-turn movement to the traffic performance of Letjen Hertasning road in Makassar City. The traffic surveys were conducted at five selected observation points at the first five median openings of Jalan Letjen Hertasning which is directly adjacent to Jl. AP Pettarani for three days at three peak hours segment which are in the morning, afternoon, and evening. The analysis of road performance follows the procedures in the Indonesian Road Capacity Manual. Research result shown that the length of vehicles queuing to finish the U-turn movement during the peak hours reached 9 vehicles with a queue length of $36 \mathrm{~m}$. This queue causes the capacity of the road to decrease by $2.5-10 \%$ of the actual capacity which causes a decrease in speed, an increase in the degree of saturation, and a reduction in the level of service of the road.
\end{abstract}

\section{PENDAHULUAN}

Permasalahan lalu lintas yang bersifat heterogen dan menjadi karakteristik kota besar di Indonesia termasuk Kota Makassar adalah kemacetan, tundaan, dan antrian yang semakin diperparah oleh faktor sosial demografi (Aly, 2012). Per tahun 2019, jumlah penduduk di Kota Makassar tercatat lebih dari 1,5 juta jiwa dengan angka pertumbuhan sebesar 1,23\% (BPS, 2020). Peningkatan jumlah penduduk berbanding lurus dengan peningkatan pergerakan kendaraan di jalan dan secara tidak langsung berkontribusi pada permasalahan kemacetan terutama jika peningkatan permintaan tersebut tidak mampu diimbangi oleh ketersediaan ruang jalan (Ali \& Abidin, 2019). Jumlah pergerakan yang berlalu-lalang di jalan arteri di Kota Makassar semakin bertambah pada siang 
hari akibat masuknya pergerakan eksternal dari daerah tetangga seperti dari Kabupaten Gowa, Takalar, dan Maros (Mahsyar, 2014). Kompleksitas kemacetan ini menjadi fenomena yang kerap terjadi di salah satu ruas jalan utama di Kota Makassar yaitu ruas Jalan Letjen Hertasning.

Peran ruas Jalan Letjen Hertasning yang menjembatani daerah administratif Kota Makassar dan Kabupaten Gowa menimbulkan eskalasi arus lalu lintas di ruas jalan ini (M. Rahman et al., 2016). Dinamika perkembangan koridor ruas jalan ini juga tergambar dari pesatnya pembangunan kawasan pemukiman dan pembangunan fungsi-fungsi ekonomi komersil dan pendidikan di sisi ruas jalan (Sakti, 2016). Selain itu, Jalan Letjen Hertasning yang berbatasan langsung dengan Kabupaten Gowa dan lingkar tengah Makassar Jl. A.P Pettarani termasuk dalam rencana pembangunan jalan akses Center Point of Indonesia (Arifin et al., 2021). Peran ruas jalan Hertasning sebagai bagian penting dari jaringan jalan perkotaan di Kota Makassar menyebabkan tingginya intensitas pergerakan kendaraan di ruas jalan ini setiap harinya. Berdasarkan klasifikasi jalan, Jalan Letjen Hertasning tergolong jalan Arteri sedangkan menurut klasifikasi penggunaan jalan, jalan ini merupakan jalan Kelas I dengan pelayanan pergerakan dua arah (Badaron et al., 2020). Ditinjau dari konfigurasi lajur, Jalan Letjen Hertasing terdiri dari enam lajur bermedian.

Fungsi pokok dari median jalan yaitu sebagai pemisah arus lalu lintas yang bergerak pada arah berlawanan, pereduksi area konflik kendaraan, dan juga sebagai pengubah kecepatan kendaraan pada lajur perlambatan/percepatan untuk lalu lintas belok kanan dan putar balik arah (Romadhona et al., 2019). Sebagai bagian dari perencanaan median, bukaan median disediakan sebagai ruang bagi pengemudi merotasi arah pergerakan kendaraan atau disebut gerakan putar balik arah disingkat menjadi gerakan PBA. Ada beberapa titik bukaan median di sepanjang Jalan Letjen Hertasning. Gerakan PBA di bukaan median seringkali mengganggu pergerakan lalu lintas menerus di ruas jalan karena saat tiba di bukaan, kendaraan yang akan putar balik arah harus menunggu tersedianya radius perputaran yang cukup untuk melakukan gerakan manuver (Sano et al., 2013). Aktivitas kendaraan di bukaan median (arus minor) tidak hanya menyebabkan keterlambatan dan antrian pada arus minor itu sendiri tetapi juga pada arus mayor, terutama pada tepi median yang berimpit dengan arus mayor untuk gerakan merging dan diverging (Radjawane, 2020).

Meskipun bukaan median telah efektif dalam pengurangan konflik lalu lintas, pengaruhnya dalam mengurangi tingkat pelayanan jalan juga dirasakan pengguna jalan yang direpresentasikan dengan parameter kecepatan berkendara dan arus lalu lintas (R. Rahman \& Ben-Edigbe, 2015). Mengukur kondisi tingkat pelayanan jalan dapat dilakukan melalui analisis kinerja ruas jalan yang diinterpretasikan berdasarkan nilai rasio arus dan kapasitas, kecepatan arus bebas, dan kapasitas ruas jalan (Setiawan et al., 2018).

Penelitian ini bertujuan untuk menganalisis pengaruh pergerakan putar balik arah terhadap kinerja ruas jalan pada Jalan Letjen Hertasning Kota Makassar. Lokus penelitian dikhususkan pada ruas Jalan Letjen Hertasning Kota Makassar, pada putar balik arah depan SPBU Hertasning sampai putar balik arah depan PT. Penerbit Erlangga. Memahami karakteristik dan penyebab kemacetan pada ruas jalan perkotaan merupakan langkah inisiasi dalam perumusan kebijakan transportasi dan rencana manajemen lalu lintas (Chow et al., 2014). Karena itu, hasil dari penelitian ini diharapkan memberi sumbangsih pada pihak terkait sebagai referensi dalam merumuskan kebijakan manajemen lalu lintas serta penataan fasilitas PBA untuk mengurai kemacetan pada ruas jalan tersebut.

\section{METODE}

Penelitian ini merupakan studi kasus dengan metode observasi berupa survei lalu lintas. Survei dilakukan 3 hari, yaitu pada Hari Senin dan Kamis yang merepresentasikan hari kerja dan Hari Sabtu yang merepresentasikan akhir pekan. Waktu pengamatan dipilih pada jam puncak pagi, siang, dan sore di tiap harinya. Terdapat lima pos pengamatan yang dipilih pada lima bukaan median pertama Jalan Letjen Hertasning yang berbatasan langsung dengan Jl. AP Pettarani. Detail prosedur penelitian dijelaskan pada sub bab berikut.

\subsection{Metode Pengumpulan Data}


Data masukan sebagai variabel untuk menganalisis kinerja ruas jalan diuraikan sebagai berikut.

Tabel 1. Variabel Penelitian

\begin{tabular}{|c|c|c|}
\hline Jenis Data & $\begin{array}{l}\text { Variabel } \\
\text { Penelitian }\end{array}$ & Metode Pengumpulan Data \\
\hline \multirow[t]{5}{*}{ Data Primer } & $\begin{array}{l}\text { Volume lalu } \\
\text { lintas }\end{array}$ & $\begin{array}{l}\text { Menghitung banyaknya kendaraan yang melintas pada pos observasi per } \\
15 \text { menit untuk masing-masing arah dengan menggunakan pencacahan } \\
\text { manual dan pencatatan pada formulir survei sesuai jenis kendaraan } \\
\text { (Zulkipli \& Yulfadli, 2017). }\end{array}$ \\
\hline & $\begin{array}{l}\text { Waktu } \\
\text { tempuh }\end{array}$ & $\begin{array}{l}\text { Data ini diperlukan untuk perhitungan kecepatan kendaraan sebagai } \\
\text { salah satu karakteristik lalu lintas. Stopwatch difungsikan dalam } \\
\text { menghitung durasi kendaraan saat melintasi segmen panjang jalan yang } \\
\text { telah ditentukan dengan dua penanda pada awal dan akhir segmen } \\
\text { (Titirlolobi et al., 2016). }\end{array}$ \\
\hline & $\begin{array}{l}\text { Panjang } \\
\text { Antrian }\end{array}$ & $\begin{array}{l}\text { Pengamatan panjang antrian dilakukan degan mengamati panjang } \\
\text { antrian kendaraan pada segmen putar balik arah yang telah ditentukan. }\end{array}$ \\
\hline & $\begin{array}{l}\text { Geometrik } \\
\text { Jalan }\end{array}$ & $\begin{array}{l}\text { Menggambarkan ukuran maupun bentuk jalan, berupa ukuran bagian } \\
\text { fisik jalan yang diamati berdasarkan penampang memanjang dan } \\
\text { melintang jalan (Lalenoh et al., 2015). Data yang diambil berupa lebar } \\
\text { badan dan bahu jalan, lebar median jalan, jarak antar bukaan median, } \\
\text { panjang ruas jalan dan fasilitas pelengkap jalan yang tersedia } \\
\text { Menggunakan roll meter. }\end{array}$ \\
\hline & $\begin{array}{l}\text { Hambatan } \\
\text { Samping }\end{array}$ & $\begin{array}{l}\text { Kategori hambatan samping untuk lingkungan sisi jalan dikalkulasikan } \\
\text { berdasarkan jumlah kendaraan parkir atau berhenti, kendaraan lambat } \\
\text { dan tidak bermotor, kendaraan keluar-masuk, serta pejalan kaki yang } \\
\text { terjadi tiap } 200 \text { m panjang jalan (Lowenta \& Najid, 2019). }\end{array}$ \\
\hline \multirow[t]{2}{*}{ Data Sekunder } & $\begin{array}{l}\text { Jumlah } \\
\text { penduduk }\end{array}$ & $\begin{array}{l}\text { Data ini menjadi basis dalam pemilihan nilai faktor penyesuaian ukuran } \\
\text { kota untuk analisis kapasitas ruas jalan (Arfandi et al., 2017). Diperoleh } \\
\text { dari situs web Badan Pusat Statistik Kota Makassar. }\end{array}$ \\
\hline & kasi & $\begin{array}{l}\text { Diperlukan dalam penentuan titik bukaan median yang akan dijadikan } \\
\text { sebagai pos pengamatan. Diperoleh dari google maps. }\end{array}$ \\
\hline
\end{tabular}

\subsection{Metode Analisis Data}

Data yang tercatat pada formulir survei lalu lintas selanjutnya dianalisis berdasarkan tahapan berikut.

a) Untuk mengetahui kinerja ruas jalan Letjen Hertasning Kota Makassar, analisis data menggunakan analisis kuantitaif berdasarkan metode Manual Kapasitas Jalan Indonesia (MKJI) tahun 1997 yaitu penentuan kapasitas (C), rasio arus kapasitas (V/C ratio), kecepatan arus bebas (FV), serta tingkat pelayanan (LOS).

b) Untuk mengetahui pengaruh pergerakan putar balik arah dilakukan analisis panjang antrian dan waktu tundaan yang terjadi saat kendaraan bermanuver pada bukaan median di tiap pos pengamatan lalu dilakukan perbandingan karakteristik lalu lintas dan kinerja ruas jalan pada lima pos pengamatan tersebut.

\section{PEMBAHASAN DAN DISKUSI}

\subsection{Geometrik Ruas Jalan}

Data geometrik jalan dikumpulkan pada lima bukaan median terpilih dengan pengukuran langsung di lapangan. Dimensi ruas jalan meliputi lebar lajur, lebar kerb, lebar bukaan, lebar median, dan jarak antar fasilitas putar balik arah merupakan variabel yang diperlukan dalam analisis kapasitas ruas jalan dan analisis karakteristik kendaraan pada putar balik arah yang ditunjukkan pada gambar 1 berikut. 


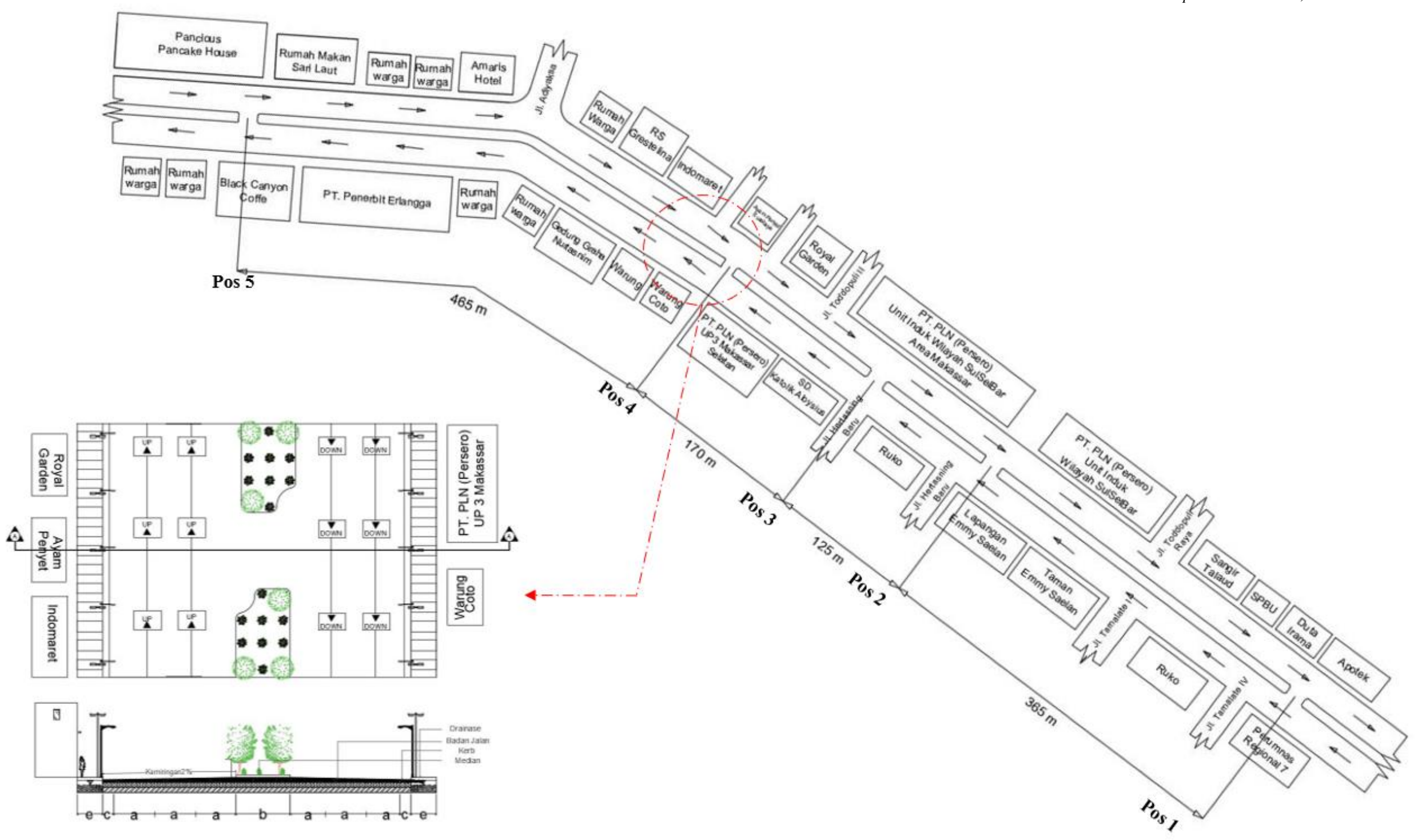

Gambar 1. Geometrik Ruas Jalan 
Gambar 1 menunjukkan letak dan jarak antara lima pos pengamatan yang dijadikan lokasi survei dalam penelitian ini. Detail potongan melintang untuk ke lima bukaan median tersebut adalah sebagai berikut

Tabel 2. Ukuran Penampang Melintang Jalan pada Bukaan Median

Keterangan: kiri: Jalur kiri (Arah menuju Gowa)

\begin{tabular}{|c|c|c|c|c|c|c|c|c|c|c|c|c|}
\hline \multirow{2}{*}{$\begin{array}{c}\text { Pos } \\
\text { Pengamatan }\end{array}$} & \multicolumn{2}{|c|}{$\begin{array}{l}\text { Lebar lajur } \\
\text { (a) }\end{array}$} & \multicolumn{2}{|c|}{$\begin{array}{l}\text { Lebar median } \\
\text { (b) }\end{array}$} & \multicolumn{2}{|c|}{$\begin{array}{l}\text { Lebar kerb } \\
\text { (c) }\end{array}$} & \multicolumn{2}{|c|}{ Lebar bukaan } & \multicolumn{2}{|c|}{$\begin{array}{l}\text { Drainase } \\
\text { (e) }\end{array}$} & \multicolumn{2}{|c|}{$\begin{array}{c}\text { Jumlah lajur } \\
\text { (f) }\end{array}$} \\
\hline & kiri & kanan & kiri & kanan & kiri & kanan & kiri & kanan & kiri & kanan & kiri & kanan \\
\hline Pos 1 & $3,50 \mathrm{~m}$ & $3,50 \mathrm{~m}$ & $3,05 \mathrm{~m}$ & $3,05 \mathrm{~m}$ & $0,3 \mathrm{~m}$ & $0,3 \mathrm{~m}$ & $12,5 \mathrm{~m}$ & 12,5 & $2 \mathrm{~m}$ & $2 \mathrm{~m}$ & 3 & 3 \\
\hline Pos 2 & $2,66 \mathrm{~m}$ & $2,70 \mathrm{~m}$ & $3,10 \mathrm{~m}$ & $3,10 \mathrm{~m}$ & $0,3 \mathrm{~m}$ & $0,3 \mathrm{~m}$ & $12,5 \mathrm{~m}$ & $12,5 \mathrm{~m}$ & $2 \mathrm{~m}$ & $2 \mathrm{~m}$ & 3 & 3 \\
\hline Pos 3 & $2,70 \mathrm{~m}$ & $2,73 \mathrm{~m}$ & $3,10 \mathrm{~m}$ & $3,10 \mathrm{~m}$ & $0,3 \mathrm{~m}$ & $0,3 \mathrm{~m}$ & $13 \mathrm{~m}$ & $13 \mathrm{~m}$ & $2 \mathrm{~m}$ & $2 \mathrm{~m}$ & 3 & 3 \\
\hline Pos 4 & $3,33 \mathrm{~m}$ & $3 \mathrm{~m}$ & $5 \mathrm{~m}$ & $5 \mathrm{~m}$ & $0,3 \mathrm{~m}$ & $0,3 \mathrm{~m}$ & $15 \mathrm{~m}$ & $15 \mathrm{~m}$ & $2 \mathrm{~m}$ & $2 \mathrm{~m}$ & 3 & 3 \\
\hline Pos 5 & $4,06 \mathrm{~m}$ & $3,33 \mathrm{~m}$ & $5 \mathrm{~m}$ & $5 \mathrm{~m}$ & $0,3 \mathrm{~m}$ & $0,3 \mathrm{~m}$ & $15 \mathrm{~m}$ & $15 \mathrm{~m}$ & $2 \mathrm{~m}$ & $2 \mathrm{~m}$ & 3 & 3 \\
\hline
\end{tabular}

kanan: Jalur kanan (Arah menuju Pettarani)

Berdasarkan aturan Bina Marga jarak antar putar balik arah adalah 500-800m. Dari hasil survei jarak antar putar balik arah pada Jalan Letjen Hertasning Kota Makassar dapat dilihat pada Gambar 1 yang artinya jarak antar bukaan di setiap pos tidak ada yang sesuai dengan peraturan yang ditetapkan dalam buku Pedoman Dirjen Bina Marga.

\subsection{Karakteristik Lalu Lintas di Jalan Letjen Hertasning}

Ada dua klasifikasi arah pergerakan yang direkapitulasi yaitu arah dari Pettarani menuju Gowa (P-G) dan arah dari Gowa menuju Pettarani (G-P). Besarnya arus lalu lintas diplot pada grafik dengan sumbu X yaitu waktu pengamatan dan sumbu Y yaitu volume kendaraan dalam satuan smp/jam. Komposisi kendaraan dengan klasifikasi berupa kendaraan ringan, kendaraan berat, sepeda motor, dan kendaraan tak bermotor kemudian dikonversi ke nilai smp/jam dengan pengali berupa nilai ekuivalensi mobil penumpang. Berikut adalah fluktuasi jumlah kendaraan yang dipilih dari nilai tertinggi antara tiga hari pengamatan setiap jamnya.

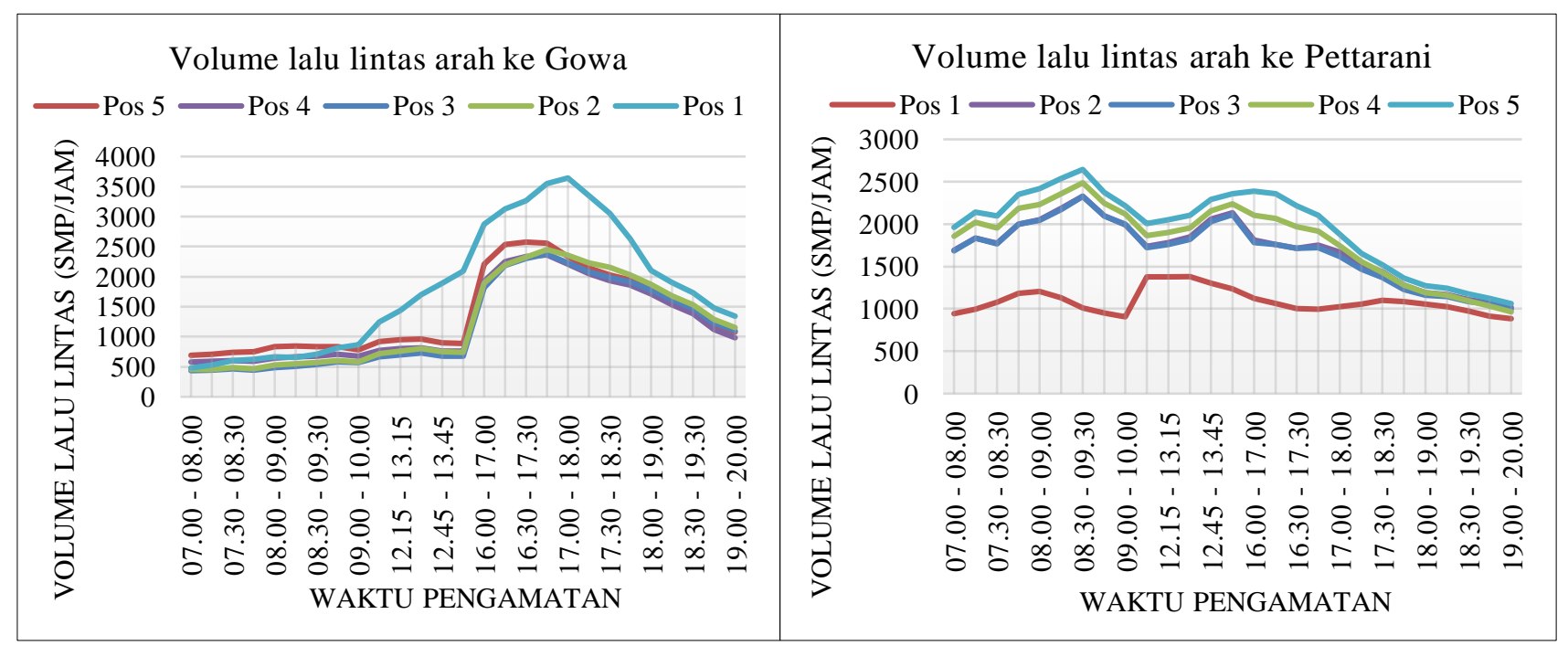

Gambar 2. Volume Lalu Lintas di Tiap Pos Pengamatan

Dari data di atas kemudian dipilih volume puncak untuk tiap pos di masing-masing arah yang selanjutnya dijadikan sebagai data masukan untuk analisis kinerja ruas jalan. Selain pengamatan arus lalu lintas, juga dilakukan perhitungan kecepatan rata-rata kendaraan berdasarkan perbandingan antara jarak segmen jalan (50 m) dengan waktu tempuh tiap kendaraan yang disajikan pada grafik berikut: 


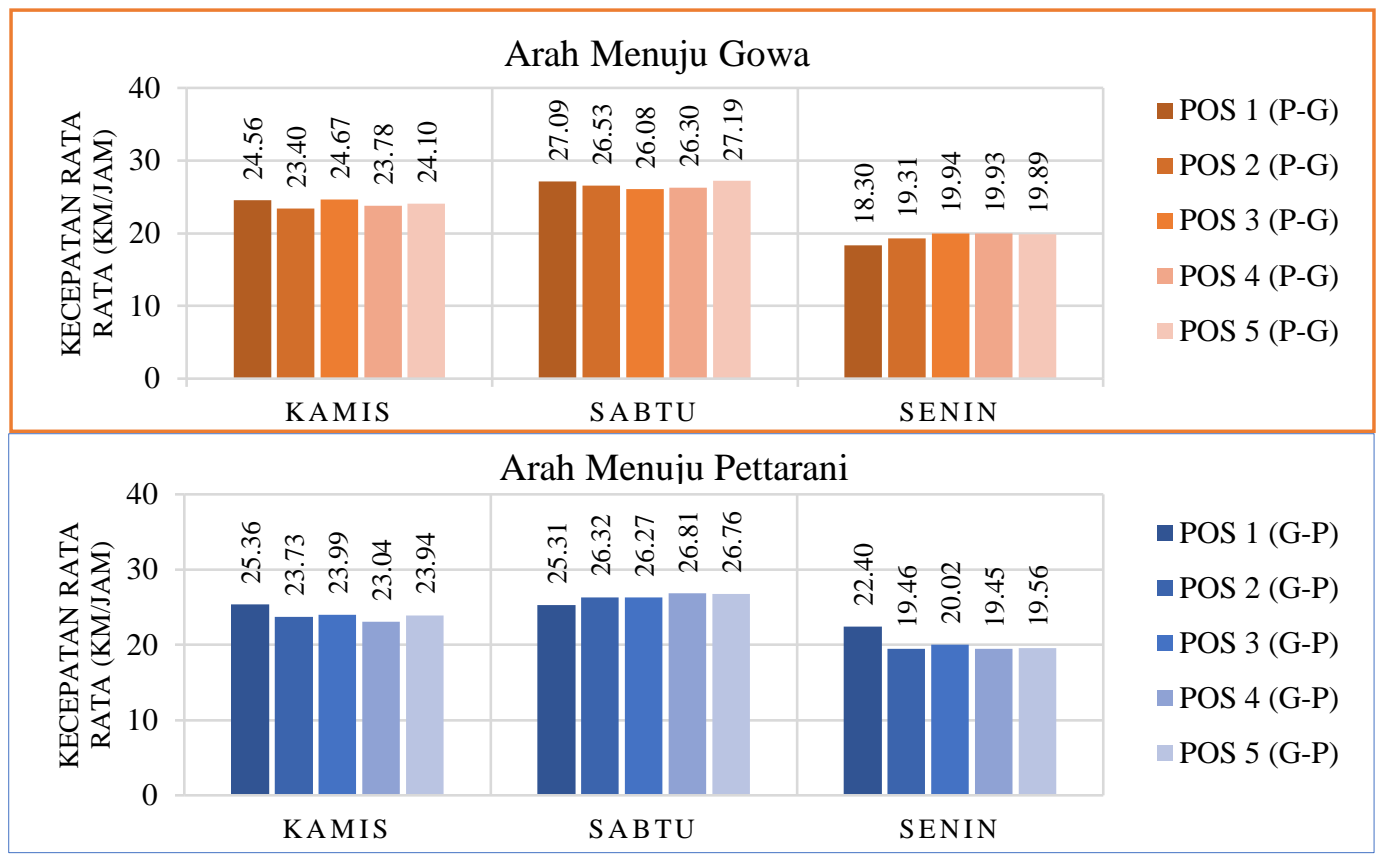

Gambar 3. Kecepatan Rata-Rata Kendaraan di Tiap Pos Pengamatan

Perbedaan kecepatan kendaraan pada setiap pos pengamatan disebabkan karena adanya antrian kendaraan yang terjadi pada titik putar balik arah yang mengakibatkan pengurangan kecepatan oleh pengguna jalan dan juga disebabkan karena padatnya kendaraan di titik tersebut baik untuk kendaraan lurus maupun yang berputar.

\subsection{Perhitungan Kapasitas Ruas Jalan Letjen Hertasning}

Perhitungan kapasitas dimaksudkan untuk mengetahui perbandingan nilai kapasitas (C) dengan nilai kapasitas dasar (Co). Perhitungan di lakukan pada 5 pos penelitian dengan menggunakan rumus pada MKJI 1997 sebagai berikut (Mudiyono \& Anindyawati, 2017):

$$
\mathrm{C}=\mathrm{Co} \times \mathrm{FC}_{\mathrm{W}} \times \mathrm{FC}_{\mathrm{SP}} \times \mathrm{FC}_{\mathrm{SF}} \times \mathrm{FC}_{\mathrm{CS}}(\mathrm{smp} / \mathrm{jam})
$$

Tabel 3. Rekapitulasi Perhitugan Kapasitas Jalan pada Tiap Pos Pengamatan

\begin{tabular}{|c|c|c|c|c|c|c|}
\hline \multirow[b]{2}{*}{$\begin{array}{c}\text { Pos } \\
\text { Pengamatan }\end{array}$} & \multirow[b]{2}{*}{$\begin{array}{l}\text { Kapasitas } \\
\text { Dasar (Co) } \\
\text { (smp/jam) }\end{array}$} & \multicolumn{4}{|c|}{ Faktor Penyesuaian } & \multirow[b]{2}{*}{$\begin{array}{c}\text { Kapasitas } \\
\text { (c) } \\
\text { (smp/jam) }\end{array}$} \\
\hline & & $\begin{array}{l}\text { Lebar } \\
\text { Jalur } \\
\text { FCw }\end{array}$ & $\begin{array}{l}\text { Pemisah Arah } \\
\text { FCsp }\end{array}$ & $\begin{array}{c}\text { Hambatan Samping } \\
\text { FCsf }\end{array}$ & $\begin{array}{c}\text { Ukuran Kota } \\
\text { FCcs }\end{array}$ & \\
\hline Pos 1 (G-P) & 4950 & 1,00 & 1,00 & 0,952 & 1,00 & 4712,40 \\
\hline Pos $2(\mathrm{G}-\mathrm{P})$ & 4950 & 0,92 & 1,00 & 0,952 & 1,00 & 4335,41 \\
\hline Pos 3 (G-P) & 4950 & 0,92 & 1,00 & 0,96 & 1,00 & 4371,84 \\
\hline Pos 4 (G-P) & 4950 & 0,96 & 1,00 & 0,96 & 1,00 & 4561.92 \\
\hline Pos $5(\mathrm{G}-\mathrm{P})$ & 4950 & 1,08 & 1,00 & 0,96 & 1,00 & 5132,16 \\
\hline Pos 1 (P-G) & 4950 & 1,00 & 1,00 & 0,96 & 1,00 & 4752,00 \\
\hline Pos 2 (P-G) & 4950 & 0,92 & 1,00 & 0,96 & 1,00 & 4371,84 \\
\hline Pos 3 (P-G) & 4950 & 0,92 & 1,00 & 0,96 & 1,00 & 4371,84 \\
\hline Pos $4(\mathrm{P}-\mathrm{G})$ & 4950 & 0,92 & 1,00 & 0,96 & 1,00 & 4371,84 \\
\hline Pos $5(\mathrm{P}-\mathrm{G})$ & 4950 & 0,96 & 1,00 & 0,96 & 1,00 & 4561,92 \\
\hline
\end{tabular}

Perhitungan kapasitas dilakukan per jalur dimana konfigurasi lajur di jalan ini yaitu 6/2 D. Perbedaan kapasitas yang terjadi pada setiap titik pengamatan disebabkan karena ruas jalan ini memiliki kondisi geomterik jalan dan hambatan samping yang bervariasi di tiap titik sehingga mempengaruhi faktor lebar jalur dan faktor penyesuaian hambatan samping. Adapun untuk faktor lainnya diperoleh nilai yang sama untuk setiap pos pengamatan. 
Pengaruh Pergerakan Putar Balik Arah terhadap Kinerja Ruas Jalan Letjen Hertasning Kota Makassar Rani Bastari Alkam, Muh. Ilham Marhabang, Muh. Ikhwan

\subsection{Perhitungan Kinerja Ruas Jalan Letjen Hertasning}

Salah satu indikator tingkat kemacetan pada ruas jalan adalah tingkat pelayanan jalan tersebut yang juga merupakan salah satu parameter dalam mengukur kinerja ruas jalan. Sebelum mengukur tingkat pelayanan, terlebih dahulu dihitung derajat kejenuhan (DS) dan kecepatan arus bebas pada tiap lokasi pengamatan menggunakan rumus berikut (Mudiyono \& Anindyawati, 2017):

$$
\mathrm{DS}=\frac{Q}{C}
$$

dimana: $\mathrm{Q}=$ Volume lalu lintas (smp/jam)

$\mathrm{C}=$ Kapasitas $(\mathrm{smp} / \mathrm{jam})$

Tabel 4. Rekapitulasi Perhitugan Kinerja Ruas Jalan

\begin{tabular}{cccccc}
\hline Pos & $\begin{array}{c}\text { Volume Lalu } \\
\text { Lintas (Q) } \\
\text { Pmpamatan }\end{array}$ & $\begin{array}{c}\text { Kapasitas } \\
\text { Ruas Jalan (C) } \\
\text { smp/jam }\end{array}$ & $\begin{array}{c}\text { Derajat } \\
\text { kejenuhan } \\
(\mathrm{DS})\end{array}$ & $\begin{array}{c}\text { Kecepatan Arus } \\
\text { Bebas (FV) } \\
\text { (km/jam) }\end{array}$ & $\begin{array}{c}\text { Tingkat } \\
\text { Pelayanan }\end{array}$ \\
\hline Pos 1 (GP) & 1380,45 & 4712,40 & 0,29 & 55,63 & B \\
Pos 2 (GP) & 2329,70 & 4335,41 & 0,54 & 51,73 & $\mathrm{C}$ \\
Pos 3 (GP) & 2325,90 & 4371,84 & 0,53 & 53,00 & $\mathrm{C}$ \\
Pos 4 (GP) & 2487,15 & 4561.92 & 0,55 & 55,00 & $\mathrm{C}$ \\
Pos 5 (GP) & 2644,65 & 5132,16 & 0,52 & 61,00 & $\mathrm{C}$ \\
\hline Pos 5 (PG) & 2644,65 & 4561,92 & 0,58 & 55,00 & $\mathrm{C}$ \\
Pos 4 (PG) & 2487,15 & 4371,84 & 0,57 & 53,00 & $\mathrm{C}$ \\
Pos 3 (PG) & 2376,10 & 4371,84 & 0,54 & 53,00 & $\mathrm{C}$ \\
Pos 2 (PG) & 2451,10 & 4371,84 & 0,56 & 53,00 & $\mathrm{C}$ \\
Pos 1 (PG) & 3643,20 & 4752,00 & 0,77 & 57,00 & D \\
\hline
\end{tabular}

Nilai pada tabel 4 menunjukkan bahwa untuk arah menuju AP Pettarani pada pos 1 dengan tingkat pelayanan B arus masih stabil dan pengemudi masih dapat bebas dalam memilih kecepatannya. Menuju ke pos 2 sampai pos 5, tingkat pelayanan di level $\mathrm{C}$ yang artinya arus masih stabil namun pengendara sudah dibatasi dalam memilih kecepatan. Sedangkan untuk tingkat pelayanan dari jalan AP Pettarani menuju Gowa berada dikategori "C" mulai dari pada pos 5 ke pos 2 dan menjadi tingkat pelayanan D di pos 1 yang menandakan arus menjadi tidak stabil, kecepatan dipilih pada interval nilai rendah dan variatif, dan jumlah kendaraan yang melintas hampir menyamai kapasitas jalan.

\subsection{Karakteristik Lalu Lintas pada Bukaan Median}

Data lain yang dikumpulkan adalah karakteristik lalu lintas untuk pergerakan putar balik arah diantaranya yaitu survei volume kendaraan yang berputar arah untuk tiap jenis kendaraan yang kemudian di konversi menjadi smp/jam.

Arah menuju Gowa

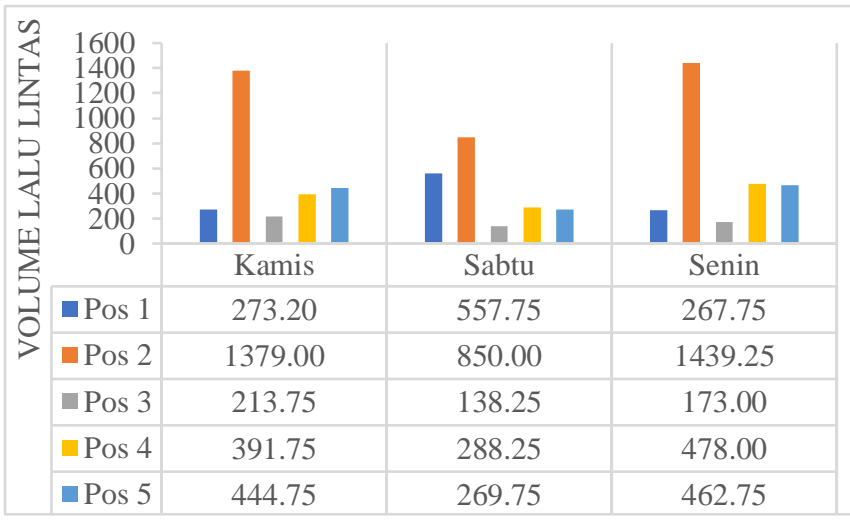

Arah menuju Pettarani

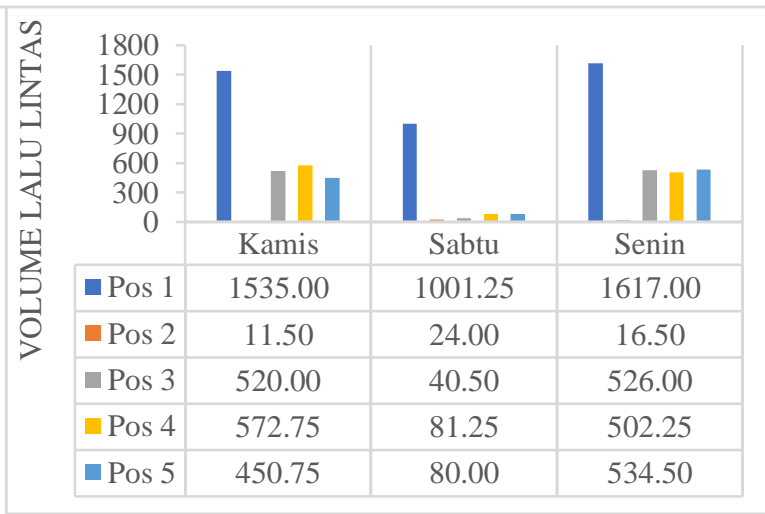

Gambar 4. Volume Kendaraan Maksimum yang Putar Balik Arah di Tiap Pos Pengamatan (smp/jam) 
Untuk kendaraan yang putar balik arah menuju Gowa, volume saat peak hour pada Hari Kamis terjadi pada pos 2 yang mencapai $1379 \mathrm{smp} / \mathrm{jam}$, pada Hari Sabtu juga terjadi pada pos 2 mencapai $850 \mathrm{smp} / \mathrm{jam}$, dan untuk Hari Senin juga pada pos 2 yang mencapai 1439 smp/jam. Hasil ini menunjukkan bahwa pergerakan putar balik arah yang paling tinggi untuk pergerakan menuju Gowa konsisten terjadi di Pos 2 (depan Taman Emmy Saelan/ PT PLN Persero). Di jalur lain yaitu untuk arus menuju Jl. AP Pettarani, data survei untuk ketiga hari pengamatan menunjukkan bahwa pergerakan putar balik arah maksimum terjadi di pos 1 (bukaan median di depan SPBU Hertasning) dengan volume maksimum untuk hari Kamis, Sabtu, dan Senin berturut-turut sebesar 1535; 1001,25; dan $1617 \mathrm{smp} / \mathrm{jam}$.

Selain menghitung jumlah kendaraan yang putar balik arah, juga dilakukan perhitungan panjang antrian dan waktu tunda kendaraan pada fasilitas putar balik arah. Untuk menganalisis panjang antrian, maka input data berupa banyaknya kendaraan yang melakukan PBA, dan durasi yang dibutuhkan kendaraan untuk menyelesaikan gerakan tersebut pada bukaan sedangkan tundaan/ waktu tunda merupakan tambahan durasi yang dibutuhkan kendaraan saat berputar yang diakibatkan oleh gangguan dari kendaraan lain disekitarnya. Pemodelan tundaan pada fasilitas PBA adalah fungsi dari volume lalu lintas dua arah di sisi median yang diformulasikan sebagai berikut (Al-Masaeid, 1999):

$$
\mathrm{TD}=6,6 \times \mathrm{e}^{\mathrm{q} / 1200}
$$

dimana:

$\mathrm{TD}=$ rata-rata total tundaan kendaraan yang melakukan PBA (detik/kendaraan)

$\mathrm{qc}=$ Arus lalu lintas dari arah yang berseberangan (smp/jam)

Nilai panjang antrian dan tundaan kendaraan disajikan sebagai berikut:

Tabel 5. Panjang Antrian Kendaraan dan Waktu Tunda Kendaraan pada Tiap Pos Pengamatan

\begin{tabular}{ccccc}
\hline $\begin{array}{c}\text { Pos } \\
\text { pengamatan }\end{array}$ & $\begin{array}{c}\text { Qc Conflicting } \\
\text { traffic flow } \\
\text { (smp/jam) }\end{array}$ & Waktu jam puncak & $\begin{array}{c}\text { Panjang antrian } \\
\text { kendaraan }(\mathrm{m})\end{array}$ & $\begin{array}{c}\text { Waktu tunda } \\
\text { (detik/kend) }\end{array}$ \\
\hline Pos 1 (G-P) & 2428,80 & $17.00-18.00$ & 24 & 49,95 \\
Pos 2 (G-P) & 491,17 & $13.00-14.00$ & 20 & 9,94 \\
Pos 3 (G-P) & 1324,17 & $17.30-18.30$ & 12 & 19,90 \\
Pos 4 (G-P) & 1498,20 & $16.15-17.15$ & 12 & 23,00 \\
Pos 5 (G-P) & 1693,20 & $16.15-17.15$ & 16 & 27,06 \\
\hline Pos 1 (P-G) & 509,53 & $17.00-18.00$ & 36 & 10,09 \\
Pos 2 (P-G) & 1171,37 & $16.15-17.15$ & 4 & 17,52 \\
Pos 3 (P-G) & 1171,37 & $16.15-17.15$ & 12 & 20,82 \\
Pos 4 (P-G) & 1378,87 & $16.15-17.15$ & 12 & 24,50 \\
Pos 5 (P-G) & 1573,87 & $16.15-17.15$ & 12 & \\
\hline
\end{tabular}

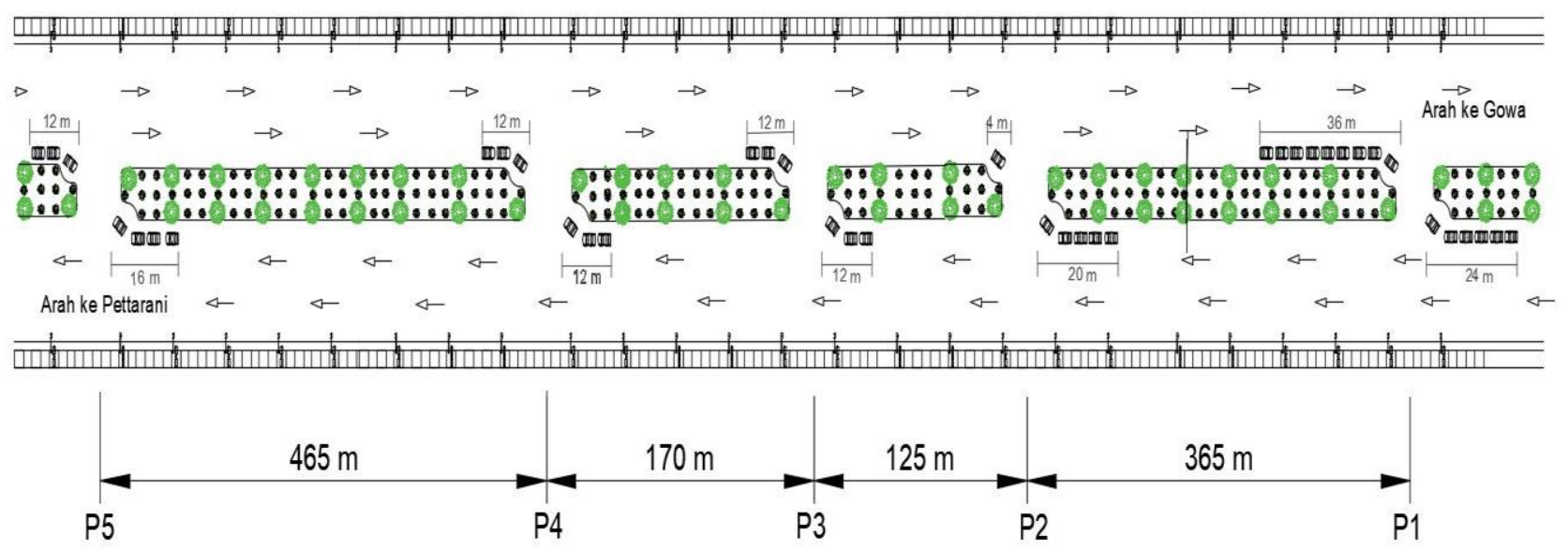

Gambar 5. Panjang Antrian Kendaraan yang Terjadi pada Tiap Pos Pengamatan 


\subsection{Diskusi}

Dari penyajian data pada sub-sub bab sebelumnya, ada beberapa hasil yang digarisbawahi peneliti berkaitan dengan pengaruh pergerakan putar balik arah terhadap kinerja ruas jalan, sebagai berikut:

a. Pada Pos 1 terjadi antrian kendaraan sepanjang $36 \mathrm{~m}$ atau sekitar 9 kendaraan yang mengantri, dimana waktu tunda setiap kendaraan dalam melakukan putar balik arah yaitu 49,95 detik/kendaraan. Panjang antrian kendaraan ini berpengaruh terhadap kapasitas jalan sekitar 10\% karena dengan adanya antrian kendaraan yang akan menggunakan fasilitas U-Turn mengakibatkan jalan yang mulanya 3 lajur menjadi 2 lajur sehingga kapasitas ruas jalan berkurang.

b. Pada Pos 2, saat jam puncak terjadi antrian kendaraan sepanjang 20 atau sekitar 5 kendaraan, dimana waktu tunda yaitu 17,52 detik/kendaraan untuk melakukan putar balik arah, panjang antrian kendaraan juga berpengaruh terhadap kapasitas jalan sekitar $7 \%$.

c. Pada pos 3, antrian kendaraan sepanjang $12 \mathrm{~m}$ atau sekitar 3 kendaraan, waku tunda 19,90 detik/kendaraan untuk melakukan putar balik arah dan panjang antrian kendaraan juga berpengaruh terhadap kapasitas jalan sekitar $7 \%$.

d. Pada pos 4 volume kendaraan yang berputar balik arah mencapai $478 \mathrm{smp} / \mathrm{jam}$, dengan panjang antrian kendaraan sepanjang $12 \mathrm{~m}$ atau sebanyak 3 kendaraan yang mengantri. Waktu tunda yaitu 20,82 detik/kendaraan dengan pengaruh pengurangan terhadap kapasitas jalan sekitar $7 \%$.

e. Pada pos 5 volume kendaraan yang berputar balik arah mencapai $462,75 \mathrm{smp} / \mathrm{jam}$ dengan panjang antrian sepanjang $16 \mathrm{~m}$ dengan perkiraan kendarsan yang mengantri sekitar 4 kendaraan dengan waktu tunda 24,50 detik/kendaraan untuk melakukan putar balik arah. Antrian ini menyebabkan pengurangan kapasitas jalan sebesar 3,5\%.

f. Dua variabel yang mempengaruhi nilai tundaan kendaraan saat berputar balik arah yaitu lebar bukaan median dan arus lalu lintas arah berlawanan.

g. Terdapat hubungan berbanding lurus antara rasio volume/ kapasitas dengan volume kendaraan yang berputar balik arah yaitu semakin tinggi volume putar balik arah, maka nilai rasio volume/ kapasitas juga semakin tinggi disebabkan adanya pengurangan kapasitas ruas jalan.

h. Pada saat pengemudi mendekati fasilitas PBA dilakukan ancang-ancang berupa pengurangan kecepatan perjalanan. Kecepatan kendaraan semakin diturunkan terutama jika berpapasan dengan kendaraan lain yang juga melakukan manuver di bukaan median yang sama. Hal inilah yang menyebabkan hasil survei kecepatan pada setiap pos-pos pengamatan dimana mengalami penurunan.

\section{KESIMPULAN}

Pergerakan putar balik arah pada lima bukaan median yang diamati menyebabkan terjadinya antrian kendaraan dengan panjang berkisar antara 4 hingga 36 m yang menyebabkan setiap kendaraan mendapatkan waktu tunda selama 9,94- 49,95 detik/ kendaraan saat bermanuver. Nilai ini dipengaruhi oleh volume lalu lintas di sekitar bukaan dan lebar bukaan median tersebut. Antrian kendaraan ini mengambil alih 1 lajur jalan dari setiap arah lalu lintas sehingga kapasitas ruas jalan berkurang sebesar 2,5-10\% dari kapasitas sesungguhnya. Pengurangan kapasitas ini menyebabkan terjadinya penurunan kecepatan, peningkatan derajat kejenuhan, dan penurunan tingkat pelayanan ruas jalan Letjen Hertasning.

\section{UCAPAN TERIMA KASIH}

Penelitian ini dapat dirampungkan karena adanya dukungan dan kontribusi dari berbagai pihak mulai dari tim surveyor yang sangat kooperatif dalam mengumpulkan data di lapangan dan juga kepada pimpinan Program Studi, fakultas, dan universitas utamanya yang berkecimpung di Lembaga Penelitian dan Pengembangan Sumber Daya UMI.

\section{DAFTAR PUSTAKA}

Al-Masaeid, H. R. (1999). Capacity of U-turn at median openings. ITE Journal (Institute of Transportation Engineers), 69(6), 28-30, 32, 34.

Ali, M. I., \& Abidin, M. R. (2019). Pengaruh Kepadatan Penduduk Terhadap Intensitas Kemacetan Lalu 
Lintas Di Kecamatan Rappocini Makassar. Prosiding Seminar Nasional Lembaga Penelitian

Universitas Negeri Makassar, 68-73. http://eprints.unm.ac.id/17795/1/prosiding Pengaruh Kepadatan Penduduk.pdf

Aly, S. H. (2012). Model Hubungan Karakteristik Makro Lalu Lintas yang Bersifat Heterogen di Kota Makassar. Prosiding Teknik Sipil Universitas Hassanudin, TS12-1-TS12-10.

Arfandi, A., Pertiwi, N., \& Rahmatan, R. (2017). Analisis Tingkat Pelayanan Jalan Andi Djemma Kota Makasar. Jurnal Inovasi Dan Pelayanan Publik Makasar, 1(1), 38-52.

Arifin, A. E. S., Surya, B., \& Salim, A. (2021). Dampak Urban Sprawl Terhadap Pola Pergerakan Studi Pada Koridor Jalan Letjend. Hertasning Kota Makassar. Urban and Regional Studies Journal, 3(1), 23-31. https://doi.org/10.35965/ursj.v3i1.606

Badaron, S. F., Watono, W., Abd. Muin, S., C.A, M. R., \& Firdaus, D. (2020). Analisa Biaya Penanganan Berdasarkan Penilaian Kondisi Jalan dengan Metode Road Condition Index (RCI) pada Ruas Jalan Hertasning. PENA TEKNIK: Jurnal Ilmiah Ilmu-Ilmu Teknik, 5(1), 11. https://doi.org/10.51557/pt_jiit.v5i1.599

BPS. (2020). Kota Makassar dalam Angka 2020 (Seksi Integrasi Pengolahan dan Diseminasi Statistik (ed.)). Badan Pusat Statistik Kota Makassar. https://makassarkota.bps.go.id/publication/download.html?nrbvfeve=YmMzYTQ3MDU0YzM4NmJh

Chow, A. H. F., Santacreu, A., Tsapakis, I., Tanasaranond, G., \& Cheng, T. (2014). Empirical assessment of urban traffic congestion. Journal of Advanced Transportation, 48(8). https://doi.org/10.1002/atr.1241

Lalenoh, R. H., Sendow, T. K., \& Jansen, F. (2015). Analisa Kapasitas Ruas Jalan Sam Ratulangi Dengan Metode Mkji 1997 Dan Pkji 2014. Jurnal Sipil Statik, 3(11), 737-746.

Lowenta, L., \& Najid, N. (2019). Penentuan Kapasitas Jalan Dua Lajur Dua Arah Tidak Terbagi Dengan Metode Mkji, Konsep Pkji, Dan Survei. JMTS: Jurnal Mitra Teknik Sipil, 2(3), 27. https://doi.org/10.24912/jmts.v2i3.5675

Mahsyar, A. (2014). Model Koordinasi Antarinstansi Pemerintah Dalam Penanggulangan Kemacetan Lalu Lintas Di Kota Makassar. Jurnal EL-RIYASAH. https://doi.org/10.24014/jel.v5i2.649

Mudiyono, R., \& Anindyawati, N. (2017). Analisis Kinerja Jalan Majapahit Kota Semarang (Studi Kasus: Segmen Jalan Depan Kantor Pegadaian Sampai Jembatan Tol Gayamsari). Prosiding Seminar Nasional Inovasi Dalam Pengembangan SmartCity, 1(1), 345-354.

Radjawane, L. E. (2020). The effect of median opening on traffic characteristics on the arterial street. IOP Conference Series: Earth and Environmental Science, 419(1). https://doi.org/10.1088/17551315/419/1/012102

Rahman, M., Haerany, H., \& Idrus, M. (2016). Pengaruh Aktivitas Perdagangan dan Jasa Terhadap Volume Lalu Lintas di Ruas Jalan Hertasning Kota Makassar. Plano Madani : Jurnal Perencanaan Wilayah Dan Kota, 5(2), 192-201. http://journal.uin-alauddin.ac.id/index.php/planomadani/article/view/1588

Rahman, R., \& Ben-Edigbe, J. (2015). Impact of Multilane Median Openings Zone on Travel Speed. Jurnal Teknologi, 73(4), 15-20. https://doi.org/10.11113/jt.v73.4279

Romadhona, P. J., Bachnas, \& Nurkumala, L. (2019). Traffic Performance of U-Turn Effects at Median Opening on Four-Lane Divided of Urban Street (Study Case: Yogyakarta, Indonesia). MATEC Web of Conferences, 280, 02002. https://doi.org/10.1051/matecconf/201928002002

Sakti, H. H. (2016). Fenomena Perubahan Pemanfaatan Ruang Dan Pertumbuhan Aktivitas Perkotaan (Kasus Koridor Ruas Jalan Hertasning - Samata di Makassar - Gowa). Plano Madani, 5(2), 171-179. http://journal.uin-alauddin.ac.id/index.php/planomadani

Sano, K., Jenjiwattanakul, T., \& Nishiuchi, H. (2013). Capacity of U-turn Junction at Midblock Median Opening on Urban Arterial Based on Balancing Volume-to-capacity Ratio. Journal of the Eastern Asia Society for Transportation Studies, 10, 1670-1686. https://doi.org/10.11175/easts.10.1670

Setiawan, A., Yunus, I., Kasmuri, M., Universitas, M., Darma, B., Universitas, D., Darma, B., Jendral, J., Yani, A., \& Palembang, N. (2018). Analisa Kinerja Ruas Jalan Pada Jalan Parameswara Kota Palembang. Jurnal Ilmiah TEKNO, 15(02), 11-22.

Titirlolobi, A. I., Elisabeth, L., \& Timboeleng, J. A. (2016). Analisa Kinerja Ruas Jalan Hasanuddin Kota Manado. Jurnal Sipil Statik, 2(Kinerja Ruas Jalan), 9.

Zulkipli, S., \& Yulfadli, Z. (2017). Pengaruh Volume Lalu Lintas Terhadap Tingkat Kebisingan pada Jalan Bung Tomo Samarinda Seberang. Kurva S, 4(1), 131-136. 